David M. Levy

\title{
CONTEMPLATING SCHOLARSHIP IN THE DIGITAL AGE
}

The role of scholarship in contemporary society has not yet been defined. Much ink will yet be spilled, perhaps blood too, before a consensus is achieved. ${ }^{1}$

Who will keep alive the values of the special collections community in the digital realm if not the collectors and curators who presently make up that community?2

In A BOOK PUBLISHED In 2001, Thomas Hylland Eriksen, a Norwegian anthropologist, describes a chance discovery that led him to new insights:

I was suddenly given an hour of empty time. I had delivered a defective lamp to the shop and found myself in a part of Oslo which I rarely visit. Due to an administrative slip on my part, my first meeting was more than an hour off, and it was going to be in the same part of town ... I strolled leisurely down the beautiful main street of the suburb (called Bygdøy Allé) in the sun, pensively licking a brightly colored ice lolly. As I reached the main roundabout near the venue of my meeting, my eye caught an enormous banner covering a large part of the front of the old University Library. "Speed 1800-1900," it said. Naturally I was drawn toward the building like a fly toward flypaper, and quite right: the library featured a small, but excellent exhibition about my topic, displaced about a hundred years back in history. Had I not been

1. Norman Lamm, "Scholarship and Piety," in Faith and Doubt: Studies in Traditional Jewish Thought (New York: Ktav Publishing House, 1971).

2. Abby Smith, "Authenticity and Affect:When Is a Watch not a Watch," Library Trends 52, no. 1 (2003). 
fooling around aimlessly that morning, I should never have even heard about the exhibition. ${ }^{3}$

That a few unscheduled moments led to a useful discovery would hardly seem worth mentioning, except that Eriksen's book, The Tyranny of the Moment: Fast and Slow Time in the Information Age, is an extended argument that "fast time" is increasingly pushing out "slow time." "Everything that can be done quickly," he says, "threatens to do away with everything that must be done slowly. As a result, slow processes are transmuted into fast ones." His anecdote is meant to illustrate the value of slow time, especially as a condition for creativity.

These days, it is hard not to notice this culturewide speedup or some of its associated manifestations: the pervasive sense of information overload as we are overwhelmed by the flood of e-mail, mass media, and the like; the fragmentation of our attention as we are constantly called to respond to our various information devices, cell phones, blackberries, and wireless computers; and the sense of being constantly overbusy and overscheduled as we try to meet the increasing demands put upon us in both our work and personal lives. The evidence is growing that living in these information-saturated, speed-dominated ways is taking its toll on us; various medical and psychological effects, for example, such as heart problems, anxiety, and depression, are demonstrably associated with the stress of living this way.

My concern in this article is with the effects of this speedup on academic life and, specifically, on scholarship. I have become an academic only recently. For a number of years, I was a researcher in a high-tech think tank, the Xerox Palo Alto Research Center. Although I certainly experienced an increased pace of life over the more than fifteen years I worked there, by the time I left in 1999, I still had periods of quality research time: stretches of time to read, think, and write. Not so these past five years, however, since I became a professor at the University of Washington. Today's academic life, I have discovered firsthand, is hardly leisurely. Almost entirely missing is the time to read and reflect; the time to muse and to absorb; the time to think. The slow time needed for scholarship is consistently overridden by the fast time of teaching and administrative duties. (And sadly, teaching and administrative work suffer too for lack of adequate time and attention.)

3. Thomas Hylland Eriksen, Tyranny of the Moment: Fast and Slow Time in the Information Age (London: Pluto Press, 2001). 
This is a curious state of affairs because today's students, faculty, and staff have access to the most powerful tools and technologies for learning and scholarship the world has ever known, including e-mail and discussion lists, word-processing and publishing software, bibliographical tools, and, of course, the World Wide Web with its online catalogs, e-journals, retrospectively digitized paper journals, and endless varieties of source materials. These tools provide students and scholars with exceptional opportunities for search, access, organization, analysis, and publication. So it is a sad irony (if I am right) that universities are failing to cultivate the ground in which scholarship can flourish at exactly the moment they are providing such excellent tools. But at the same time it is entirely understandable that universities, no longer remote ivory towers, are subject to the same forces as the rest of the culture. Why should professors be any less overloaded, overbusy, and overworked than anyone else in the culture?

I don't mean to suggest that scholarly work is no longer being done in the academy. Academics still write scholarly articles and books, more than ever before; and at least in the sciences, they get large research grants and supervise hordes of graduate students. My concern is that today's academic conditions are less and less supportive of the full range of scholarly practices. But I have some hope that this can be rectified, for there are still corners of the university-in libraries and special collections, for example-where the contemplative roots of the modern university are still visible.

$$
* * *
$$

A chance discovery of my own launched me on an exploration of the roots of the problem. In the fall of 2002, I taught a course on hypertext in the Textual Studies Program at the University of Washington, a course meant to introduce students to the uses of digital materials for scholarly and literary purposes. One of the first assigned readings was "As We May Think," the July 1945 Atlantic Monthly article by Vannevar Bush, which is famous for its first imagining of hypertext (the idea "whereby any item may be caused at will to select immediately and automatically another") and for its influence on key hypertext figures, including Douglas Englebart, Ted Nelson, and Tim Berners-Lee (recently knighted for his work in creating the World Wide Web). Ted Nelson, credited with coining the terms hypertext and hypermedia, has said that Bush's article is often cited, but rarely read. In truth, I had never read it until I assigned it to the class. 
What I found there greatly surprised me. In the sixty years since its publication, the essay has been endlessly cited and celebrated, and justifiably so. But virtually all the attention has gone to the central section of the paper, where Bush imagines a device he calls the memex that will have the ability to link sections of text to one another. In reading the paper along with my students, I found my attention drawn elsewhere, to the beginning and end of the article, where Bush explains why we should build his imagined device. An engineer by training, Bush saw the world in terms of problems needing solving. The problem he identified, and he hoped the memex would solve, is a problem we now call information overload. As Bush noted in the sixth paragraph of the article:

There is a growing mountain of research. But there is increased evidence that we are being bogged down today as specialization extends. The investigator is staggered by the findings and conclusions of thousands of other workers-conclusions which he cannot find time to grasp, much less to remember, as they appear. Yet specialization becomes increasingly necessary for progress, and the effort to bridge between disciplines is correspondingly superficial. ${ }^{4}$

Ah, you might say, plus ça change: ours clearly isn't the first era to suffer from information overload. Although this is certainly true, it misses the fact that Bush's proposal was intended to temper, if not fully eliminate, the problem. ${ }^{5}$ And sixty years later, after the development of an amazing array of new technologies, some directly inspired by Bush, the problem hasn't gotten better; it has arguably gotten worse. So what went wrong?

The answer, I believe, can be found in the work of another thinker, who published a small book at virtually the same time and who addressed some of the same conditions as Bush, but who came up with very different answers. In 1948, Josef Pieper, a German philosopher and theologian, published Musse und Kult, which appeared in two different English translations under the title Leisure: The Basis of Culture in $1952^{6}$ and 1998. ${ }^{7}$ If Bush was concerned about information overload, Pieper was

4. Vannevar Bush, “As We May Think," Atlantic Montbly (July 1945): 641-49.

5. See, for example, an entire issue of the Journal of the History of Ideas (64, no. 1 [Jan. 2003]) devoted to "Early Modern Information Overload."

6. Josef Pieper, Leisure:The Basis of Culture, trans.Alexander Dru, introd.T. S. Eliot (New York: Pantheon, 1952).

7. Josef Pieper, Leisure:The Basis of Culture, trans. G. Malsbary (South Bend, Ind.: St. Augustine's Press, 1998). 
concerned with the emergence of a world of "total work." "[T] he world of work is becoming our entire world," he said, "it threatens to engulf us completely, and the demands of the world of work become greater and greater, till at last they make a 'total' claim upon the whole of human nature." Bush's proposed solution was the development of new technologies; Pieper's was radically different: the recovery of leisure.

But by leisure Pieper didn't mean what is typically meant today: pursuing recreational activities and time off ("Freedom from time-consuming duties, responsibilities, or activities," according to the American Heritage Dictionary, Fourth Edition). Instead, he meant the recovery of the ancient Greek notion of leisure, that is, contemplation. For the Greeks, leisure was the highest good, the ultimate aim of human life, and work was a lesser, though still necessary, form of activity. Work was what needed to be done for the sake of something else: spinning wool in order to make clothing, lighting a fire in order to keep warm, building a house in order to be sheltered from the elements. Leisure, by contrast, was that which required no justification beyond itself; philosophy, the arts, and the celebration of festivals fell under this category for the Greeks because they were simply an expression of the human spirit and its true life in the world.

The Western world, Pieper argued, had largely lost its awareness of, and its contact with, the reflective or receptive dimension of life. Leisure, he said, "is a form of stillness that is the necessary preparation for accepting reality; only the person who is still can hear, and whoever is not still cannot hear. Such stillness as this is not mere soundlessness or a dead muteness ... Leisure is the disposition of receptive understanding, of contemplative beholding, and immersion in the real." He noted that the words school, scholar, and scholarship are all derived from the Latin schola, which is itself derived from the Greek word for leisure (skhole).

The medieval scholastics (quite literally the first "scholars"), Pieper noted, recognized two modes of thinking, which they called ratio and intellectus. Ratio is "the power of discursive thought, of searching and re-searching, abstracting, refining, and concluding, whereas intellectus refers to the ability of 'simply looking,' to which the truth presents itself as a landscape presents itself to the eye." The scholastics considered ratio to be a form of work; intellectus, however, was leisurely in the

8. Ibid. 
original Greek sense: quiet, contemplative, reflective. Thinking for the scholastics was inevitably a mixture of these two modes: hard, directed problem solving combined with periods of apparent idleness.

Both Bush and Pieper wanted to support thinking and reflection in the postwar world. Bush hoped that the devices he was proposing, including the memex, would help automate the more repetitive aspects of the human thought process, freeing people to pursue thought's more creative aspects. (He did, after all, call his article, "As We May Think.") Pieper was clearly responding to both a concern for the future, that people caught up in the frenzy of work would have no time to think, and Germany's recent past, which demonstrated a profound failure of moral thinking and its devastating consequences.

So my little journey of discovery began with shock and surprise: the realization that the advances Bush hoped would solve a particular problem have apparently exacerbated it. It continued with my happening upon Pieper's reflections on contemplation and scholarship, which were written at roughly the same time. And through the juxtaposition of these two radically different perspectives, I came to a formulation of what's gone wrong with our latest technologies and what's currently missing from scholarship. As I see it now, the suite of digital tools we presently have, including, but not limited to, the World Wide Web, are superb instruments for ratio-for searching and re-searching, abstracting, refining, and concluding. Indeed, they are probably the best tools for ratio the world has ever known. But in the process of creating them, and creating the conditions for using them, we have apparently failed to leave room for, let alone to acknowledge, intellectus.

Scholarship encompasses a broad spectrum of activities. It includes the work of searching for sources, analyzing and making cross-connections, publishing, speaking, defending, and so on. But it also depends on certain uses of time: for deep reflection, for absorption in one's materials. And, I will claim, it even depends on activities that can appear unrelated to, and unnecessary for, one's work, such as taking walks, having casual and undirected conversations, and reading in unrelated areas. These practices don't easily fit into a world in which we are constantly interrupted and in which we keep running, like the Red Queen, trying desperately not to fall further behind. Universities today do a great job 
of providing access to the technologies and materials of scholarship, but they are doing a poor job of providing the conditions, the space and time, that support the contemplative side, the intellectus, of scholarly work.

$$
* * *
$$

This brings me, at last, to libraries and special collections. In August, 2002, I came across a two-page advertisement in the Sunday New York Times magazine for the IBM Thinkpad laptop, the very machine on which I'm now writing these remarks. It showed a man wearing a business suit sitting with his laptop open on his lap. What caught my attention wasn't the man himself but, rather, where he was sitting: in the stacks of a library. The ad copy read, "In deep halcyon repose," and below this it gave the dictionary definition for halcyon as "peaceful." What the ad was saying seemed clear enough: You can take this laptop anywhere, even to places such as the library, where you'll get some peace and quiet.

Certainly, the library has this image even today. Its negative face is that of the shushing librarian, so delightfully parodied in the Nancy Pearl librarian action figure. Its positive face is as a place, a protected physical place, a sanctuary, where one can read, reflect, study, contemplate; and it is this facet the IBM ad so clearly plays upon. The library in our culture is a cultural symbol not only of the search for knowledge and wisdom, but also of the practices through which this search is conducted. In practice, the library has tried to support this search not just by collecting materials, organizing, and providing access to them, but also by creating physical spaces and other conditions, such as quiet, that encourage it. If the library as a whole carries this weight, so, too, do special collections, only more so, for they are the "Sanctum sanctorum" of the library, in David Stam's words. ${ }^{9}$

Special collections, as readers of this journal know better than I, are those institutions charged with preserving and providing access to certain materials deemed "special." And in providing access, they also create and maintain conditions conducive to what I will call reverent attention. To "revere," according to the dictionary, is to "regard with awe,

9. David H. Stam, "So What's So Special?," paper read at "Building on Strength: Developing an ARL Agenda for Special Collections," June 28, 2001, Providence, R.I. http://www.arl.org.special/ stam.html. 
deference, and devotion." The Indo-European root of reverent is wer-, which means to "perceive and to watch out for." From this root come words such as wary, aware, reward, and guard, as well as revere. In this etymology, there is clearly a link between perceiving or paying attention to something and caring for it. And this seems just right, for in my experience close attention generally leads to wonder and awe and care. Close regard, or reverent attention, is a crucial dimension of scholarship.

Special collections are those places, then, that enable a close encounter, a reverent and direct engagement, with special materials. And this, says David Stam, is what makes special collections so special. "That is the answer to the question, what's so special; for me personally and for many students I've observed over the years, it is the palpable connection to history that comes from the tactile experience of touching the rare book or unusual manuscript. It's a conversion experience: seeing them under glass with unturnable pages just doesn't do the same thing." ${ }^{10}$ Something happens, again and again, when people encounter these materials.

On many occasions I, too, have felt the lure of this specialness and have observed it in my students. For the past five years, with Sandra Kroupa, the book arts and rare book curator at the University of Washington Libraries, I have taught a course on the history of recorded information that makes extensive use of materials in special collections. When we explore the history of the letter, for example, Sandra brings out original Civil War letters, which she reads from and allows students to handle. One of the required assignments asks students to reflect on the personal significance of the hands-on elements of the course (which also include learning to bind a simple book and elementary writing with a broadedged [i.e., calligraphic, pen]). From these wonderful, and often quite moving, responses it is clear that historical artifacts have the ability to connect people to the past, making it literally more tangible and present.

Any artifact, in fact, whether deemed special by the larger culture or not, whether historically significant or not, has the potential to instruct us and inform us when engaged with reverent attention. And special collections are places devoted to reverent attention, a dimension of scholarship that is in danger of being overwhelmed by the speedy, shallow mode of inquiry that is most common today. So special collections are special not 
just because their materials are special or because they afford a special encounter with these materials, but because they are guardians (from the Indo-European root wer-) of a mode of attention and inquiry that extends beyond the particulars of the materials they collect and provide access to.

My aim here isn't primarily to make the case for special collections today, to argue for funding and protecting them, although I certainly believe in the importance of this; rather, it is to suggest that special collections professionals have certain kinds of knowledge and understanding that ought to be-need to be-inserted into discussions of the future of libraries, scholarship, and the academy. In a sense, my argument parallels Abby Smith's in her article, "Authenticity and Affect," and can be seen as a further application or extension of it. She calls on special collections librarians to bring their expertise to bear on certain intractable problems concerning digital materials, in particular understanding "the artifactual value of a digital object as a primary source" and figuring out how this value can be preserved.

"There are already urgent pleas," Smith says, "from faculty, scholars, and other users of digital collections for expert curators and collectors to define the artifactual value of a digital object as a primary source that warrants the same attention to selection, curation, and preservation as analog special collections." And it would be a great loss "to research and collecting communities present and future if that work were left entirely to commercial producers of digital content and the technical communities that design, build, and operate computer systems and write software codes. It is time for libraries and archives to encourage actively the development of digitally literate curators ... Who will keep alive the values of the special collections community in the digital realm if not the collectors and curators who presently make up that community?"11

Smith here urges special collections librarians to apply their skills and knowledge to certain problems with digital materials; I want to urge the same group to apply their skills and knowledge to certain problems with the digital age. Terry Belanger has suggested that " $[\mathrm{t}]$ he codex book is going the way of the horse: a noble beast, but one increasingly used for recreational purposes, decreasingly used elsewhere." ${ }^{12}$ I don't want to lose the book anymore than do readers of this journal, but I am far more concerned about the loss, or the serious diminishment, of practices that

11. Smith, "Authenticity and Affect."

12. Terry Belanger, "Afterword," Library Trends 52, no. 1 (2003). 
have long been supported by the book, including the slow, reflective processes that are necessary for certain forms of scholarship. We must be clear that the media and technologies are not, in and of themselves, the issue: we might retain the codex and the great treasures of special collections but lose the time and the institutional support to study them; and conversely, we have the potential to support the scholarly, the reflective, the contemplative, in the digital age, regardless of the status of books and historical materials. This won't happen, though, unless those of us who value this dimension are articulate about its importance.

I don't mean to sound naïve about this. I realize that librarians, as much as any profession, feel compelled to do more than ever before and to do it faster. Adding one more agenda item to an already unworkable list would seem crazy. And yet, simply acquiescing to the cultural mandate to go faster, to produce more, and, as a direct consequence, to eliminate time for thought, reflection, and contemplation is even crazier, surely a prescription for disaster. The modern environmental movement was born forty years ago as people came to understand that unchecked urbanization and industrialization would destroy the planet's natural balance. Isn't it possible that we are discovering an analogous danger - that unchecked acceleration and information profusion is destroying our human balance?

$$
* * *
$$

If Vannevar Bush were alive today (he died in 1974 at the age of 84), what would he think of the developments his ideas have wrought? An engineer to the core, he would certainly be excited by the technical advances that have been achieved in the past sixty years. Digital computers were just being invented when he first conceived of the memex, and he based his ideas on microfilm, the most advanced recording medium of his day. He would surely recognize that the great advantages of the digital medium. What's more, he thought of the memex as a stand-alone machine, an individual workstation. There is little doubt that he would be delighted by the global reach of the World Wide Web.

But at the same time, there is plenty of evidence that he would be disturbed by the continuing speedup of life and the loss of time for reflection. Bush clearly hoped that the memex, by automating and otherwise supporting the more routine aspects of thinking and scholarship, would allow people more time to reflect, not less. He also believed in the creative dimension of supposedly idle time. According to his biographer, G. Pascal Zachary, he jealously guarded his free time. "I think hobbies are 
necessary for anyone who is compelled to work under strain," Bush said in $1951 .{ }^{13}$ And although still an academic in the 1930s, he worried that university education was degenerating into the acquisition of shallow bits of information and "forgetting points." "The student is hounded," Bush observed in 1933. "His hours are crowded and closely scheduled; he has little time for reading or reflection, and he does little such. All but the exceptional students become automatons." ${ }^{14}$ He worried that without time and the encouragement to reflect more broadly, students would not be able to acquire, or retain, a sense of the larger whole. (This was clearly one of the motives behind the invention of the memex: the desire to counteract the effects of specialization and blinkered thinking.)

So what happened? How did Bush's ideas become the vehicle for ever more crowded schedules and speedy lives? Perhaps it was inevitable that computers would figure in the economic speedup that has dominated Western life since at least the Industrial Revolution. But I can think of two somewhat more specific factors that played out in ways Bush couldn't, or at least didn't, foresee.

By the end of World War One, according to Colin Burke in Information and Secrecy: Vannevar Bush, Ultra, and the Other Memex, "improvements in printing, communications and transportation [had] created a bundle of opportunities and frustrations that ... began to be called the 'library' problem." ${ }^{15}$ This problem manifested itself differently to different constituencies. For the general public, the issue was unequal access to books and the cost of library materials. For scientists, it was "the inability of the traditional library to serve its most important client, the scientific researcher." The memex was Bush's response to the library problem.

For Bush and the scientists who first identified this problem, the solution seemed clear enough: to provide better technical means to access the record outside the jurisdiction of librarians. An "information system for science" would address those library roles and practices they considered central to their work that weren't being adequately handled by traditional libraries. They focused on the management of collections. But, as I suggested earlier, libraries then played another vital role-that of providing an environment conducive to thought and reflection. In the 1930s and

13. G. Pascal Zachary, Endless Frontier:Vannevar Bush, Engineer of the American Century (New York: Free Press, 1997).

14. Ibid.

15. Colin Burke, Information and Secrecy:Vannevar Bush, Ultra, and Other Memex (Metuchen: Scarecrow Press, 1994). 
1940s, however, there was no reason for scientists to pay particular attention to this role and therefore no reason to define the library problem to include this concern within its scope. Bush could assume that if the access problem was solved, researchers would have the time they needed to reflect.

Of course, once World War II began, speed was of the essence. Bush headed up an organization called the Office of Scientific Research and Development, which oversaw the development of new weapon systems and other critical technologies; the fate of the free world might well depend on their successful deployment. He saw his job as mobilizing civilian scientists (in Zachary's words) "to apply their talents to military needs, [and to] discard their leisurely academic pace and rush pell-mell for the finish line."16 But my guess is that he never imagined that the sense of urgency would carry on beyond the war; instead, he would have expected that scientists, at least in the academy, would return to their much cherished and more leisurely pursuit of truth.

What happened instead we know only too well. Albert Borgmann, a philosopher of technology, calls our society "hyperactive" and likens it to "a state of mobilization where the richness and variety of social and cultural pursuits and the natural pace of daily life have been suspended to serve a higher, urgent cause."17 Borgmann wrote these words more than a decade ago, and they seem only more pertinent today. The sense of urgency has found its way into all quarters of life-business, academia, home life-and is being felt by children at an increasingly early age. Elementary school districts across the country have been banning recess, a response to "the pressures of the world marketplace." Karyn Clarke, for example, assistant superintendent of the Tacoma, Washington school district, explains that "Our mission is in preparing young people to compete in global society." 18

The first draft of this article was written while I was in residence at the John W. Kluge Center at the Library of Congress. My office was in the Jefferson building, and I spent a portion of each day sitting in the magnificent reading room, surrounded by books and articles and my

16. Ibid.

17. Albert Borgman, Crossing the Postmodern Divide (Chicago: University of Chicago Press, 1992).

18. Gregory Roberts, "Tacoma Elementaries Engforce Ban on Recess; Goal is 'Maximizing Instruction Time," Seattle Post-Intelligencer (18 September 2004):A, 1. 
laptop, much like the advertisement for the IBM Thinkpad. Alternating between reading, writing, and gazing around me, I marveled at how a physical space so visually interesting and busy, filled with sculpture, inscriptions, and elaborate decorative elements, could be so calming and inspiring, not distracting. Surely, I thought, there is much to learn here about how to create online environments that are more conducive to contemplation and reflection. For the resolution of the problem I have been discussing will not come from creating spaces just like the Library of Congress's reading room, nor by giving everyone access to special collections on a daily basis. But I do hold out the hope that the learning and inspiration we gain from successful spaces such as our reading rooms and the practices they enable, and from the professionals who guard these spaces and practices, can be applied to the creation of new spaces, both physical and virtual, that honor and support the contemplative dimension of learning and scholarship.

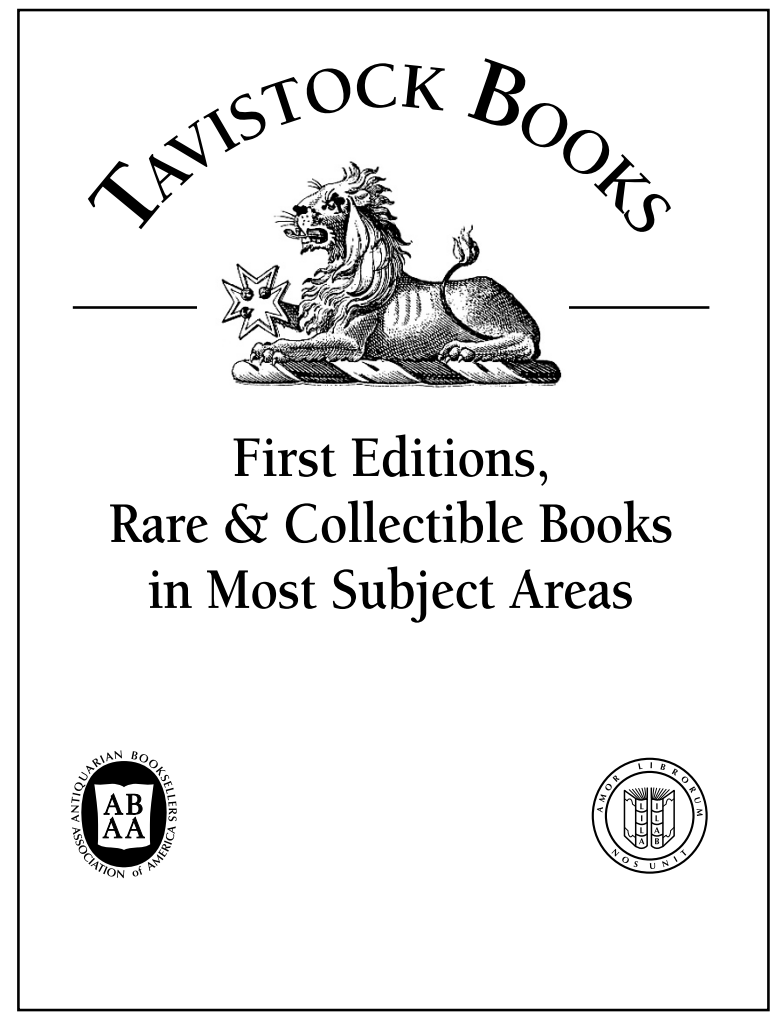

